\title{
JOB SATISFACTION: INVESTIGATING THE ROLE OF EXPERIENCE AND MOTIVATION OF UNIVERSITY ACADEMICIANS IN PAKISTAN
}

\author{
Munazza Rahim Hanafi ${ }^{*}$ \\ Khalid Iraqi $^{* *}$
}

\begin{abstract}
The key resource for the achievement of institutional objectives and enhancement of high quality education are teachers. Well motivated and satisfied teachers cultivate the successful education system in the country. Thus, the present study attempts to observe the impact of motivation and experience on job satisfaction of teachers through the perspective of Herzberg's ideology of employee motivation and job satisfaction by conducting the comparative study of both public and private sector universities in Karachi. The sample was purposively drawn from 300 teachers and the data was analyzed by using partial least squares - Structural Equation Modeling (SEM). Additionally, significant differences were found in the job satisfaction and motivation level among private and public university teachers. The presented findings embrace the implications for higher education institutions and HR practitioners.
\end{abstract}

Keywords: Intrinsic motivation, extrinsic motivation, job satisfaction, Structural Equation Modeling (SEM)

\section{Introduction}

Education is considered as the primary organization for a country and plays a dominant role in its development (Stankovska et al. 2017) ${ }^{1}$. Higher education institutions (HEIs), are recognized as a source that creates and cultivate knowledge and regarded as awareness production institutes for various fields and domains of life and ensures highquality education (Khalid et al., 2012) ${ }^{2}$. In higher education institutions, teachers are a key resource and hold a major role in determining the achievement of institutional objectives and fostering a successful education system. Bently et al. ${ }^{3}$ (2013) postulated that in order to determine the success of university's mission and vision, a vital contribution is made by teachers, and the said contribution relies on sufficient level of job

\footnotetext{
* Munazza Rahim Hanafi, Ph.D. Scholar, Department of Public Administration, University of Karachi

${ }^{* *}$ Khalid Iraqi, Ph.D. Professor, Department of Public Administration, University of Karachi

${ }^{1}$ Stankovska, G., Angelkoska, S., Osmani, F., \& Grncarovska, S. P. Job Motivation and Job Satisfaction Among Academic Staff in Higher Education. Bulgarian Comparative Education Society, (2017).

${ }^{2}$ Khalid, S., Irshad, M. Z., \&Mahmood, B. "Job satisfaction among academic staff: A comparative analysis between public and private sector universities of Punjab, Pakistan." International Journal of Business and Management 7, no. 1 (2012): 126

${ }^{3}$ Bentley, P. J., Coates, H., Dobson, I. R., Goedegebuure, L., \& Meek, V. L. "Factors associated with job satisfaction amongst Australian University Academics and Future Workforce Implications. In Job Satisfaction Around the Academic World." (Springer, Dordrecht, 2013): 29-53
} 
satisfaction among them. Likewise, it is argued by Machado-Taylor et al. ${ }^{4}$ (2010) that among teachers, the essential elements which contribute towards the quality of education provided by universities are motivation and job satisfaction. Also, job satisfaction among academic personnel is crucial for student's satisfaction as it creates the highest impact on the learning of students and enhancing the quality of education.

According to Hezberg (1959), "job satisfaction is a measure of an employee's over-all attitude towards his job, whether he likes or dislikes it" Kalleberg (1997) it is the "overall affective orientation on the part of individuals toward work roles which they are presently occupying." definitions that, the performance of employees and the overall productivity and organizational success depends on the satisfaction of its employees and thus the same phenomenon of human behavior is followed in the education sector also. The major sources of job satisfaction are working environment, income, age, experience and the level of motivation among employees (Fritsche, 1996) ${ }^{7}$. Motivation refers to the "inner drive that pushes individuals to act or perform a specific task" (Locke \& Lethem, 2004). According to Pinter (1998) motivation with the job is "the set of internal and external forces that initiate job-related behavior and determine its form, direction, intensity, and duration"'. From the discussed definitions it can be stated that job motivation stimulates the process of goal achievement among individuals and generates the required behavior aimed at achieving the targeted goal. The satisfaction level of an individual with the job is determined by the extrinsic and intrinsic motivation factors, with their social connectivity among the colleagues, and from the degree to which the goals of an individual are achieved. The factors that account for intrinsic satisfaction comprises the responsibility and underlying teaching activities, whereas the extrinsic factors of motivation that affected teacher's satisfaction include, compensation packages, the climate of the organization, supportive work environment in form of support from supervisors and co-workers and facilitating working conditions. It is more likely that the satisfied and motivated teachers possess high enthusiasm for goal achievement and contributes towards the success of the institution form which they are associated with $(\text { Daft, 2005) })^{10}$.

\section{Rationale of the Study}

Around the globe, a plethora of studies examined the trend that exists on job satisfaction and motivation towards work but the scarcity of findings was observed in the local

\footnotetext{
${ }^{4}$ Machado-Taylor, M. L., Meir Soars, V., \&Gouveia, O. "The Role of Job Motivation Among Academic Staff University." Global Business and Economics Anthology 2, no. 2 (2010): 242-246

${ }^{5}$ Herzberg, Frederick. "The Motivation to Work, 1959." The Ultimate Business Library, (New York: Holy Wiley \& Sons, 2003): 5

${ }^{6}$ Kalleberg, Arne L. Nonstandard Work, Substandard Jobs: Flexible Work Arrangements in the US (Washington, D.C.: Economic Policy Institute, 1997).

${ }^{7}$ Fritsche, K. Job Satisfaction of Texas Dietician. UMI, (1996).

${ }^{8}$ Locke, Edwin A., and Gary P. Latham. "What Should We Do About Motivation Theory? Six Recommendations for the Twenty-First Century". The Academy of Management Review. 29, No. 3 (2004): 388403.

${ }^{9}$ Pinder, Craig C. Work Motivation in Organizational Behavior. (London: Taylor \& Francis, 2008).

${ }^{10}$ Daft, R. L., \& Lane, P. G. The Leadership Experience (3rd). Mason, (Ohio: Thomson South-Western, 2005).
} 
environment specifically in the context of higher education institutions and teachers. Currently, according to the Higher Education Commission of Pakistan statistics (2019), there are 197 universities in Pakistan, in which 117 are public universities and the remaining 80 are private universities. A number of HEIs are operated in Karachi, Sindh. Presently, there are 31 private universities and 15 public universities are imparting higher education in the fields of medicine, engineering, agriculture, veterinary sciences and general disciplines in Karachi, Pakistan. ${ }^{11}$

In HEIs, job satisfaction of teachers becomes crucial for ensuring the quality of education and satisfaction among students. Moreover, it is also concerned with the economic development of the country. During the last few years, the active role played by HEC in Pakistan exerts increased pressure on higher education institutions for quality enhancement. Thus, in the present scenario, the satisfaction and motivation of teachers become more essential with the increased number of competition among the institutes specifically in the private sector imparting higher education within the country. The attractive compensation packages and benefits are offered in order to recruit the best talent and offering high-quality education. Whereas, in public sector, the focus is only directed towards salary to boost teacher's motivation and satisfaction levels which makes it difficult for them to compete the diversified compensation packages offered by the private sector in form of career development opportunities, empowerment of teachers, effective performance appraisal systems and skills development through training. However, the limited findings within the perspective of motivation and level of job satisfaction of teachers in higher education institutions in Pakistan emerges the need for further exploration that how the job satisfaction of teachers in Pakistan is affected by the motivational characteristics including intrinsic and extrinsic motivational factors which are present in their working environment and how their demographic characteristics affect the relationship between the two.

\section{Objective of the Study}

Based on the aforementioned observation, the present study aims to examine the impact of motivation and demographic characteristics on job satisfaction of teachers through the lens of Herzberg's ideology of employee motivation and job satisfaction by conducting the comparative study of both public and private sector universities. The higher education institutes of Karachi, the largest city of Pakistan was selected for the analysis. Additionally, the purpose is to attain a deeper understanding regarding the level of job satisfaction phenomenon and the factors associated with it by answering the research question concerning the impact of motivation and experience on job satisfaction among university teachers of public and private sector in Pakistan. The earlier studies have examined job satisfaction through different statistical approaches as per the study objectives. However, in the present research, the job satisfaction among teachers and their level of motivations are analyzed by using "structural equation modeling (SEM)" approach in order to make a methodological contribution to present the comparisons between motivation and satisfaction levels among the teachers of public and private

\footnotetext{
${ }^{11}$ https://www.hec.gov.pk/english/universities/Pages/AJK/Universities Statistics.aspx (Accessed on 5th
} April,2019) 
universities. The study also makes an empirical contribution with the fulfillment of the literature gap that exists in the context of higher education institutions pertaining to job satisfaction.

\section{Significance of the Study}

The current research holds significance for the human resource practitioners, Human resource managers and authorities of higher education institutions to deal with the issue of teacher's motivation and satisfaction enhancing the quality of education. The results of the study provide the basis for an in-depth understanding of the factors that account for motivation among teachers and the implementation of HR practices that led towards job satisfaction.

\section{Structure of the Study}

The rest of the paper comprises of the following sections. In section 2, the background of the conceptual framework and the development research hypotheses are reported. Section 3 describes the methodology of research, whereas, in section 4, the statistical analysis of data and results are presented. Finally, the study is concluded in section 5.

\section{Conceptual Model and Hypotheses Development Conceptual Background}

The present research uses a theoretical concept on the basis of Herzberg's framework of "employee motivation and job satisfaction" 12 . The idea of "employee motivation" proposed by Herzberg provides a perspective through which the variables that lead to job satisfaction among teachers are categorized. Herzberg (1959), identified two essential factors that affect job satisfaction and dissatisfaction among employees in his classical study "The Motivation to Work". An interview of 203 managerial employees had been taken and the respondents were asked regarding the reasons behind their satisfaction and dissatisfaction with their work. These two factors are: motivation and maintenance. Maintenance factors which are also called as hygiene factors are the ones that are exclusive of the individual's perception of his/her job, instead they are organizational factors comprises of culture of the organization, policies of the company, working conditions, and support from supervisors and co-workers. The underlying issues with these factors lead towards dissatisfaction with the job.

On the contrary, it is argued that the major source of job satisfaction among employees are the internalized motivation factors which includes recognition, advancement opportunities, compensation packages and appraisal. A relationship had been described by Herzberg et al. (1959) ${ }^{13}$ between satisfaction with the job and motivational levels of the employees. It is argued that the determinants of job satisfaction are extrinsic and intrinsic motivational factors. Several studies have supported findings of Herzberg and found the strong association between motivational factors and job satisfaction (Srivasta et

\footnotetext{
${ }^{12}$ Herzberg, F. Op.cit.
}

${ }^{13}$ Ibid. 
al. 2010) $)^{14}$. Therefore, the utilization of Herzberg's insights concerning the work motivation found to be a perspective with high explanatory power that predicts the factors which are affecting job satisfaction among teachers. Based on the above discussion, the study incorporates the following research model presented in figure 1 by taking into account the motivational characteristic comprising of "intrinsic and extrinsic motivation" as an independent variable that can predict the job satisfaction among teachers of private and public sector universities in Pakistan, whereas, demographic characteristics including age, gender, and experience are considered as moderating variable through which the nature of relationship between motivation characteristics and job satisfaction can be determined.

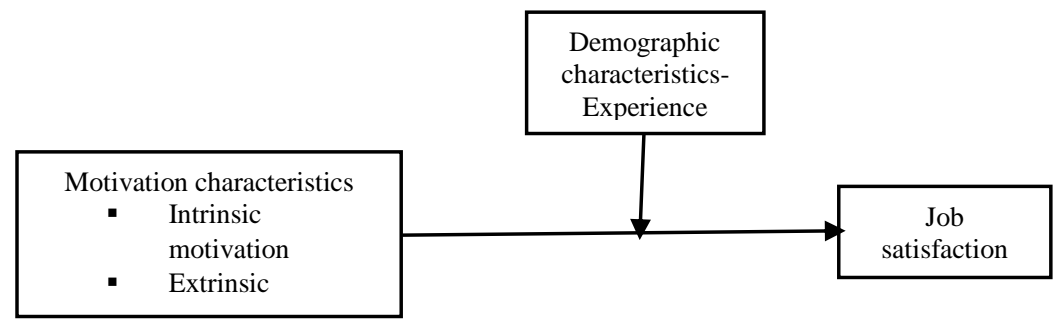

\section{Figure 1: Conceptual Framework Source: Author's construction}

\section{Hypotheses Development}

Job Satisfaction In the field of human resource management and organizational behavior, job satisfaction of employees had been considered a crucial element for the success of any organization, following this reason it has been considered a remarkable discussion perspective in various studies and the inclination towards this concept had been increased in recent years (Kosteas, 2011) ${ }^{15}$. Job satisfaction is defined by Locke (1983) as a "pleasurable or positive emotional state resulting from the appraisal of one's job or job experiences" (p. 1328) ${ }^{16}$. Similarly, it is suggested by him that that the level of job satisfaction is associated with "the attainment of values which are compatible with one's needs". Job satisfaction explains the behavior of employees regarding their jobs and the fulfillment of assigned objectives. It revealed that what are the conditions that led towards employee happiness and what causes dissatisfaction (Ramayah et al. 2001) ${ }^{17}$.

${ }^{14}$ Srivastava, A., Locke, E. A., Judge, T. A., \& Adams, J. W. "Core Self-evaluations as Causes of Satisfaction: The Mediating Role of Seeking Task Complexity." Journal of Vocational Behavior, 77, no. 2 (2010): 255-265

${ }^{15}$ Kosteas, V. D. Job Satisfaction and Promotions. Industrial Relations: A Journal of Economy and Society, 50, No.1(2011): 174-194

${ }^{16}$ Locke E. The Nature and Causes of Job Satisfaction. In: Dunnette M, Hough L, editors. The Handbook of Industrial and Organizational Psychology. (Palo Alto, CA: Consulting Psychologists Press, 1976), pp. 13191328

${ }^{17}$ Ramayah, T., Jantan, M., \& Tadisina, S. K. Job Satisfaction: Empirical Evidence for Alternatives to JDI. In 32nd Annual Meeting of Decision Sciences Institute Conference, Track OB2, (San Francisco: USA, November, 2001). 
Likewise, it is concluded by Rao (2005) that job satisfaction leads towards positive employee behaviors and is the result of higher motivation levels among the employees. ${ }^{18}$

The key factors that determine job satisfaction level of employees includes monetary compensation, incentives, rewards and motivational factors. In comparison, the weightage of other benefits like non-monetary compensation in the determination of job satisfaction is less than monetary ones (Aswathappa, 2003) ${ }^{19}$. In the same way, the benefits of job satisfaction were discussed by Velnampy $(2008)^{20}$, while studying attitude towards job and performance of employees. It is concluded that job satisfaction exerts positive impact on employee performance and results in involvement with the job and cultivates the feeling of organizational commitment among employees.

In the same vein, it is indicated by Bently et al. $(2013)^{21}$, that in higher education institutions, the satisfaction of teachers with their job is considered as the determinant of success. It is postulated that in order to ensure the performance of academicians', it is essential to provide the healthy working conditions and climate which not only results in job satisfaction but also boost their level of motivation. Also, it is evident from the research findings that a healthy working climate comprises of several factors including facilitating working conditions, interpersonal relationships, academic support, compensation packages, and opportunities of promotion along with skills development etc. (Noordin \& Jusoff, 2009) ${ }^{22}$. However, it is suggested by Lufthansa $(2005)^{23}$ that it is mandatory for an organization to direct its attention towards supervision, promotions, pay scales, work environment and motivational factors in order to ensure high level of satisfaction among its employees as the discussed factors are found to be the highest predictors of job satisfaction.

\section{Motivation Characteristics}

The word motivation originates from the Latin word "movere", which refers "to carry or to move". It is the force through which people are induced constantly to perform the specific tasks. Similarly, motivation is defined as the psychological phenomenon through which any behavior stimulates and it provides the direction of behavior, also it is the cause of its persistence ${ }^{24}$. A voluntary facet was added to the perspective of motivation by multiple researchers which is direction towards goal. Thus, the motivation of an individual is "a psychological process that initiates the arousal, provides direction and

\footnotetext{
${ }^{18}$ Rao Subba P. Essential of HRM \& Industrial Relationships, (2005):480-482

${ }^{19}$ Aswathappa k. Human Recourse \& Management, (2003): 244-245

${ }^{20}$ Velnampy, T. Job Attitude and Employees Performance of Public Sector Organizations in Jaffna District, Sri Lanka. GITAM Journal of Management, 6, No.2, (2008): 66-73

${ }^{21}$ Bentley, P. J., et.al. Op.cit.

${ }^{22}$ Noordin, Fauziah, and Jusoff, Kamaruzaman. Levels of Job Satisfaction Amongst Malaysian Academic Staff. Canadian Center of Science and Education, 2009.

${ }^{23}$ Lufthansa, F. Organizational Behavior. (McGraw-Hills International Edition, 2005)

${ }^{24}$ Ibid.
} 
results in persistence of actions that are directed towards a goal (Hellriegel \& Slocum, $1976)^{25}$.

Within the perspective of academia, eleven motivational characteristics were identified by Sinclair $(2008)^{26}$, which are specified into two dimensions namely, intrinsic and extrinsic factors. The factors that account for intrinsic motivation includes: "aspiration to working with students, intellectual stimulation, altruism, authority and leadership, selfevaluation and personal and professional development". Extrinsic motivation comprises of the following factors: "career change, working conditions, life-fit, influence of others and nature of teaching work"

According to Milne $(2007)^{27}$, among motivation programs for employees, the most favorable factors include rewards and incentives. And the satisfaction among employees with their jobs is the result of external conditions and psychological circumstances. In addition, the achievement of motivation depends upon the fulfillment of needs of the employees. Moreover, it is found that the rewards offered by an organization increase the level of job satisfaction among its employees. Salary appraisals and promotions are the strongest predictors of high level of employee motivation (Kiviniemi et al, 2002) ${ }^{28}$.

Correspondingly, it is highlighted by Chiu et al. $(2002)^{29}$ that, the motivation level of employees are affected by merit based pay systems for achieving the specific goals. And the progress of organizations depends upon the successful implementation of motivation and reward programs which results in high growth and performance along with the highest level of motivation.

\section{Motivation Characteristics, Demographic Characteristics and Job Satisfaction}

The organizational success is driven by the mutual efforts of its concerned members. Several motivational characteristics plays a prominent role in governing the relationship of employees and organizations as it determines the level of job satisfaction, which is found to be the strongest factor for growth and goal achievement. It is summarized by Bentea $(2012)^{30}$ that employee motivation is significantly associated with employee performance and satisfaction levels both at organizational and individual end.Moreover, a number of factors had been explored in earlier research findings that contributed towards the high or low level of job satisfaction among the employees such as an organization's

${ }^{25}$ Hellriegel, D., Slocum, J. W., \& Joyce, W. F. Instructor's Manual for Organizational Behavior: Contingency Views. (West Publishing Company, 1976).

${ }^{26}$ Sinclair, C. Initial and Changing Student Teacher Motivation and Commitment to Teaching. Asia-Pacific Journal of Teacher Education, 36, No.2 (2008): 79-104.

${ }^{27}$ Milne, P. Motivation, Incentives and Organisational Culture. Journal of Knowledge Management, 11, No.6 (2007): 28-38.

${ }^{28}$ Kiviniemi, M. T., Snyder, M., \& Omoto, A. M. Too Many of a Good Thing? The Effects of Multiple Motivations on Stress, Cost, Fulfillment, and Satisfaction. Personality and Social Psychology Bulletin, 28, No.6 (2002): 732-743

${ }^{29}$ Chiu, R. K., Wai-Mei Luk, V., \& Li-Ping Tang, T. Retaining and Motivating Employees: Compensation Preferences in Hong Kong and China. Personnel Review, 31, No.4(2002): 402-431.

${ }^{30}$ Bentea, C. C., \&Anghelache, V. Teachers' Motivation and Satisfaction for Professional Activity. ProcediaSocial and Behavioral Sciences, 33(2012): 563-567. 
mission and vision, its management system, supervisor relationship, interpersonal connectivity with colleagues, pay and benefits structure and motivation.

Likewise, a close linkage between motivation and job satisfaction was it evident in the prior literature. It is found by Noordin and Jusoff $(2009)^{31}$ that the job satisfaction of teachers depends upon their motivation levels. The higher the level of motivation, the higher job satisfaction was attained. On the contrary, the low motivation level of teachers led towards low level of job satisfaction among them. In addition, Nadim $(2012)^{32}$, summarized in the study findings that a fundamental role is played by employee motivation in determining the level of job satisfaction among teachers. He confirms that motivation characteristics are the factors that causes satisfaction behavior among employees and give them an optimistic view.

Similarly, the predictors of job satisfaction are divided in to three factors which includes: intrinsic factors, extrinsic factors and autonomy. "The desire to teach, smooth interpersonal relationships between students and teachers, emotions of self-efficacy, recognition and praise and enthusiasm of achievement" lies under the umbrella of intrinsic motivational factors. On the other side, the elements of extrinsic motivational factors are "facilitating working conditions, monetary rewards, pay scale, and promotions etc." which contributed a lot towards teacher's job satisfaction levels and boosts their inspirations of teaching (Sharabyan, 2011) ${ }^{33}$.

Furthermore, it is explored in prior researches within the context of higher education institutions that demographic characteristics comprising of the variables such as age, education, income, tenure, working experience, current position and income have a significant statistical role in determining the relationship between motivation and job

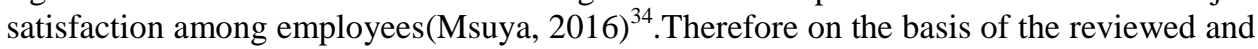
discussed literature, the present study hypothesized that:

H1: There is a significant association between extrinsic motivation and job satisfactions among university teachers.

$\mathrm{H} 2$ : There is a significant association between intrinsic motivation and job satisfactions among university teachers.

H3: Total teaching experience moderates the relationship between extrinsic motivation and job satisfactions among university teachers.

\footnotetext{
${ }^{31}$ Noordin, Fauziah, and Jusoff, Kamaruzaman. Levels of Job Satisfaction Amongst Malaysian Academic Staff. (Canadian Center of Science and Education, 2009).

${ }^{32}$ Nadim, M., Chaudhry, M. S., Kalyar, M. N., \&Riaz, T. Effects of Motivational Factors on Teachers' Job Satisfaction: A Study on Public Sector Degree Colleges of Punjab, Pakistan. The Journal of Commerce, 4 , No.4(2012):25.

${ }^{33}$ Sharabyan, S. K. An Investigation into Iranian Language Teachers' Motivation with respect to their Job Satisfaction and Second Language Pedagogy. Procedia-Social and Behavioral Sciences, 30, (2011): 1071-1075.

${ }^{34}$ Msuya, O. W. Exploring levels of job Satisfaction among Teachers in Public Secondary Schools in Tanzania. International Journal of Educational Administration and Policy Studies, 8, No.2(2016): 9-16.
} 
H4: Total teaching experience moderates the relationship between intrinsic motivation and job satisfactions among university teachers.

\section{Research Methodology}

In order to investigate the impact of motivational characteristics including extrinsic and intrinsic motivation on job satisfaction among public and private university teachers along with the moderating effect of demographic characterizes, the following methodology is employed by the present study.

\section{Target Population and Research Design}

The target population selected for this study were the teachers of public and private universities of Karachi. The sample was drawn in line with the study objective through a purposive sampling approach in order to select the respondents from both public and private sector universities. The reason behind the selection of this approach is its concentration on respondents with the specific characteristics who are able to assist in achieving the purpose of research (Etikan et al. 2016) ${ }^{35}$.

Moreover, the research design of the present study is based on correlation. As the study aims to investigate the impact of motivation on job satisfaction of university teachers along with the moderating effect of experience. The hypothesized relationships were analyzed on correlation basis in order to find out their significance or insignificance along with the explanatory power of the selected variables.

\section{Research Approach}

Research approach or research philosophy embraces the overall paradigm of the research. The philosophical approach for the present study is quantitative. The motive behind the selection of this approach is to analyze the impact of motivation and experience on job satisfaction among university teachers of public and private sector in a more detailed manner as it enables profound understanding of the research problem and potential consequences (Newman and Benz, 2006) ${ }^{36}$.

In the present study the conceptual framework is developed on the basis of reviewed literature. It is assumed that motivation characteristics in the organization creates an impact on job satisfaction of university teachers in both private and public sectors. It is further proposed that experience and other demographic characteristics moderates the relationship between motivation and job satisfaction. The conceptual relationship is supported by the job satisfaction and motivation framework proposed by Herzberg in 1959.

\footnotetext{
${ }^{35}$ Etikan, I., Musa, S. A., \&Alkassim, R.S. Comparison of Convenience Sampling and Purposive Sampling. American Journal of Theoretical and Applied Statistics, 5, No.1(2016): 1-4.

${ }^{36}$ Newman, Isadore, and Carolyn R. Benz. Qualitative-Quantitative Research Methodology: Exploring the Interactive Continuum. Carbondale, Ill: Southern Illinois Univ. Press, 2006.
} 


\section{Sample Size and Data Collection}

The data collection tool selected for the purpose of data collection is questionnaire. A survey was conducted for obtaining the responses through sending the questionnaires to teachers belonging to private and public sector universities.

The sample size for the present study is 330 respondents from whom the participation is taken through a survey based on questionnaire. The sample size is proposed on the basis of guidelines provided by "Comrey and Lee (1992), according to the book, the sample of 50 is considered as poor, 300 as good, 500 as very good and 1000 was considered as excellent sample with respect to factor analysis. Initially a pilot study with 50 respondents is conducted in order to test the reliability and validity of the measurement instrument." After completion of data collection, 300 valid responses are selected for data analysis after the removal of unqualified responses and outliers and the finals ample sample consists of 150 private university teachers and 150 public university teachers.

\section{Measurement instrument}

All the measurement items were adapted from the prior literature. The details of the adapted scales are given below:

\begin{tabular}{ll}
\hline Measurement Instrument & Source \\
\hline Job satisfaction & Saleem et al. (2010) \\
Intrinsic Motivation & Raza et al. (2015) \\
Extrinsic Motivation & Stankovska et al. (2017) \\
\hline
\end{tabular}

\section{Statistical Techniques}

The research model is analyzed with, "PLS-SEM partial least squares method to structural equation modeling". Data is analyzed through two sub models i.e. measurement model and the structural model by using the smart PLS 3.1.6 (Ringle, Wende, \& Becker, $2015)^{37}$.

Moreover, the convergent and discriminant validity of the scales have been assessed. For the evaluation of convergent validity, individual factor loadings, Cronbach's $\alpha$, composite reliability (CR) and average variance extracted (AVE) scores were analyzed. The criterion of Fornell \& Larcker (1981) were also used for convergent validity which is the degree of confidence to which a trait is well measured by its indicators. For evaluating discriminant validity, firstly the square root of AVE for each construct were analyzed through summary statistics. Secondly, the cross loading analysis were evaluated along with heterotrait-monotrait ratio of correlations.

${ }^{37}$ Ringle, C. M., Wende, S., and Becker, J.-M. SmartPLS 3, SmartPLS GmbH: Boenningstedt: 2015 
In addition, to determine the predictive relevance of the hypothesized path model, blindfolding is performed Whereas, for determining the predictive accuracy of the path model, $\mathrm{R}^{2}$ values are also determined.

\section{Ethical Consideration}

Voluntary participation was ensured throughout the process of data collection. Moreover personal information of the participants remained anonymous and utilized solely for the purpose of research.

\section{Data Analysis and Results}

Data was analyzed by using the smart PLS 3.1.6 (Ringle, Wende, \& Becker, 2015) ${ }^{38}$. PLS-SEM holds popularity in a wide range of fields which includes organization management, accounting, hospitality management, operations management, tourism, marketing and management information systems (Hair et al. 2011, Ringle et al. 2015) ${ }^{39}$.

The PLS-Structural equation model includes two sub models which are the measurement model and the structural model. The structural paths between the constructs are represented with the structural model which was used in order to determine the predictive power of the research model and for examining the relationships which are hypothesized. Whereas, the relationship between each construct and its associated indicators are represented with the measurement model, which was used to determine the reliability along with the convergent and discriminant validity of the research model.

The reasons behind the PLS selection is that it allows the estimation of complex causeeffect relationships with many constructs and indicator models without any restrictions on distribution of variables, especially when the objective is to predict the relationships (Wang et al., 2015). Moreover it is applicable on both small as well as large sample models, besides it enables flexibility with respect to the requirements of data and relationship specification between indicator variables and constructs (Hair et al., 2011) ${ }^{40}$.

\section{Demographic Analysis}

The profile of the respondents in terms of age, gender, education level, experience, and university sector in which they are working are represented below in table 1.

\footnotetext{
${ }^{38}$ Ibid.

${ }^{39}$ Hair, J. F., Ringle, C. M., \& Sarstedt, M. PLS-SEM: Indeed a Silver Bullet. Journal of Marketing Theory and Practice, 19, No.2(2011): 139-152. \& Ringle, C. M., Wende, S., and Becker, J.-M. SmartPLS 3, SmartPLS GmbH: Boenningstedt: 2015

${ }^{40}$ Hair, J. F., Ringle, C. M., \& Sarstedt, M. PLS-SEM: Indeed a Silver Bullet. Journal of Marketing Theory and Practice, 19, No.2(2011): 139-152.
} 
Table 1

Profile of respondents $(\mathrm{N}=300)$

\begin{tabular}{|l|c|c|}
\hline Demographic items & Frequency & Percentile \\
\hline Gender & & \\
\hline Male & 185 & $61.6 \%$ \\
\hline Female & 115 & $38.33 \%$ \\
\hline Education level & & \\
\hline Masters & 89 & $29.66 \%$ \\
\hline MS/M. Phil & 142 & $47.34 \%$ \\
\hline PhD & 69 & $23 \%$ \\
\hline Age & & \\
\hline $20-25$ years & 9 & $3 \%$ \\
\hline $26-30$ years & 36 & $12 \%$ \\
\hline $31-35$ years & 124 & $41.33 \%$ \\
\hline $36-40$ years & 85 & $28.33 \%$ \\
\hline Above 40 years & 46 & $15 \%$ \\
\hline University sector & & \\
\hline Private & & $15 \%$ \\
\hline Public & 150 & $50 \%$ \\
\hline Experience & 150 & $50 \%$ \\
\hline Less than a year & & \\
\hline $1-3$ years & 27 & \\
\hline $4-6$ years & & \\
\hline $7-9$ years & & \\
\hline Above 10 years & & \\
\hline & & \\
\hline
\end{tabular}

Source: Author estimations

According to the statistics shown in table 1, with respect to gender, $61 \%$ are male teachers, while $38.33 \%$ of them are female teachers. The educational profile of respondents was according to the set criteria by the HEC Pakistan for university level teaching and fell into three categories. The educational level starts from Master's Degree, than MS/M.Phil leading to the highest Degree PhD respectively. The data shows that, 
$29.66 \%$ had done Masters in their fields, majority of the respondents that is $47.34 \%$ have MS/M.Phil Degrees, whereas $23 \%$ of the respondents are PhD holders respectively which supports the HEC criteria for teaching faculty.

In terms of age, a higher percentage of teachers which is $41 \%$ lies in the category of 31 to 35 years of age, whereas $28 \%$ teachers were in the category of 36 to 40 years, $12 \%$ of the teachers were in the age category of 26-30 years and teachers who aged above 40 years are $15 \%$, while only $3 \%$ teachers belongs to the age bracket of 20 to 25 years.

Further, in terms of university sector, $50 \%$ of the teachers belongs to private sector universities of Karachi and the remaining $50 \%$ belongs to public sector universities. Similarly, with reference to total teaching experience, it implies that majority of the respondents i.e. $41 \%$ holds the experience of one to three years in the teaching profession, $9 \%$ of the teachers have an experience of less than one year, $24 \%$ of the teachers have an experience of four to six years, while $15 \%$ of the teachers holds an experience of seven to nine years and a few i.e. $10 \%$ were in the teaching profession from more than 10 years.

\section{Measurement Model Results}

Measurement model determine the reliability and validity of the construct. It is first evaluated by examining scale reliability, convergent validity and discriminant validity.

\section{Examining the reliability and validity of the construct Construct Reliability}

In the present study, construct reliability or internal consistency is measured in terms of "cronbach's alpha, composite reliability and individual factor loadings" on their respective constructs. The results of the construct reliability are represented in table 2 .

It is shown from the table that all of the individual factor loadings are significant as they are above the proposed criteria of 0.55 (Tabachnik \& Fidell, 2007) ${ }^{41}$, (Raza \& Hanif, $2013)^{42}$ and 0.7 (Hair et al., 2011) ${ }^{43}$.

The composite reliability scores of each of the constructs construct including Extrinsic motivation, Intrinsic motivation and Job satisfaction satisfies the recommended criteria for it as it should be greater than 0.7 (Hair et al., 2011) ${ }^{44}$. It is indicated from the table 2 that all Composite Reliability scores $(\mathrm{EM}=0.855, \mathrm{IM}=0.740, \mathrm{JS}=0.822)$ which offers a better estimate of variance shared by the respective indicators, and cronbach's $\alpha$ values $(\mathrm{EM}=0.786, \mathrm{IM}=0.578, \mathrm{JS}=0.741)$ are greater than proposed level of greater than 0.55 (Tabachnik \& Fidell, 2007), which provides the support for scale reliability

\footnotetext{
${ }^{41}$ Tabachnick, B. G., \& Fidell, L. S. Using Multivariate Statistics, (2007).

${ }^{42}$ Raza, S. A., \& Hanif, N. Factors Affecting Internet Banking Adoption Among Internal and External Customers: A Case of Pakistan, (2011).

${ }^{43}$ Hair, J. F., Op.cit.

${ }^{44}$ Ibid.
} 


\section{Convergent Validity}

The "Convergent validity of the construct is the degree of confidence to which a trait is well measured by its indicators" (Campbell and Fiske, 1959). For the evaluation of convergent validity, average variance extracted (AVE) scores were analyzed. Table 2 represents the results of convergent validity.

Furthermore, the criterion of Fornell \& larcker $(1981)^{45}$ was used for analyzing convergent validity of the proposed constructs comprising the path model i.e. extrinsic motivation, intrinsic motivation and Job satisfaction. For the adequate convergent validity the average variance extracted (AVE) values should be greater than 0.5. As indicated from the table all the scores of AVE are above $0.5(\mathrm{EM}=0.644, \mathrm{IM}=0.596, \mathrm{JS}=0.638)$ so it can be stated that the research model fulfills the requirement of convergent validity.

Table 2

Measurement model results

\begin{tabular}{|c|l|l|l|l|}
\hline Construct & Loadings & $\begin{array}{l}\text { Cronbach's } \\
\text { Alpha }\end{array}$ & $\begin{array}{l}\text { Composite } \\
\text { Reliability }\end{array}$ & $\begin{array}{l}\text { Average Variance } \\
\text { Extracted (AVE) }\end{array}$ \\
\hline & 0.727 & & & \\
\hline & 0.619 & & & \\
\hline EM & 0.673 & 0.786 & 0.855 & 0.644 \\
\hline & 0.867 & & & \\
\hline & 0.776 & & & \\
\hline & 0.732 & & & \\
\hline IM & 0.789 & & & 0.596 \\
\hline & 0.539 & 0.578 & 0.740 & \\
\hline & 0.764 & & & \\
\hline & 0.725 & & & \\
\hline & 0.595 & & & \\
\hline JS & 0.558 & & & \\
\hline & 0.786 & 0.741 & 0.822 & \\
\hline & 0.678 & & & \\
\hline & 0.603 & & & \\
\hline
\end{tabular}

${ }^{45}$ Fornell, C., \& Larcker, D.F. Evaluating Structural Equation Models with Unobservable Variables and Measurement Error. Journal of Marketing Research, 18, No.1(1981): 39-50. 


\section{Discriminant Validity}

The discriminant validity "is the degree to which measures of different traits are unrelated" (Campbell and Fiske, 1959). It is analyzed by using cross loadings analysis, AVE analysis and heterotrait-monotrait ratio of correlation.

\section{Fornell \& Larcker Criterion}

For the adequate discriminant validity, firstly the square root of AVE for each construct should be greater than the correlation involving the constructs (Fornell\&larcker, 1981).In other words the diagonal which is shown in correlation matrix table 3 represents the square root of AVE and implies that the correlation matrix for each construct including Extrinsic motivation, Intrinsic Motivation and Job satisfaction is below the square root of AVE of each construct which fulfills the first criteria of the discriminant validity of the employed scale

Table 3

Fornell and Larcker Criterion

\begin{tabular}{|c|c|c|c|}
\hline Construct & EM & IM & JS \\
\hline EM & 0.737 & & \\
\hline IM & 0.709 & 0.781 & \\
\hline JS & 0.645 & 0.629 & 0.662 \\
\hline
\end{tabular}

Notes: 'EM = Extrinsic Motivation, IM = Intrinsic Motivation, $J S=$ Job satisfaction'”

'The numbers shown in bold face on diagonal represents the square root of AVE for each construct. While the off diagonal part shows the correlations'

\section{Cross Loadings Analysis}

Cross loading analysis which is represented in table 4 shows that all the item loadings on their respective constructs were higher than all of its cross loadings, along with this the cross loadings differences were also greater than the proposed criteria of 0.1 (Gefen \& Straub, 2005) ${ }^{46}$.

Table 4

Cross Loadings Analysis

\begin{tabular}{|c|c|c|c|}
\hline Construct & EM & IM & JS \\
\hline EM1 & 0.727 & 0.533 & 0.438 \\
\hline EM2 & 0.619 & 0.485 & 0.367 \\
\hline EM3 & 0.673 & 0.475 & 0.431 \\
\hline
\end{tabular}

${ }^{46}$ Gefen, D., \& Straub, D. (2005). A Practical Guide to Factorial Validity Using PLS-Graph: Tutorial and Annotated Example. Communications of the Association for Information Systems, 16(1), 5. 


\begin{tabular}{|c|c|c|c|}
\hline EM4 & 0.867 & 0.580 & 0.589 \\
\hline EM5 & 0.776 & 0.543 & 0.518 \\
\hline IM1 & 0.576 & 0.732 & 0.631 \\
\hline IM2 & 0.465 & 0.789 & 0.602 \\
\hline IM3 & 0.389 & 0.539 & 0.342 \\
\hline IM4 & 0.544 & 0.764 & 0.554 \\
\hline JS1 & 0.546 & 0.613 & 0.725 \\
\hline JS2 & 0.387 & 0.408 & 0.595 \\
\hline JS3 & 0.262 & 0.520 & 0.558 \\
\hline JS4 & 0.458 & 0.637 & 0.786 \\
\hline JS5 & 0.538 & 0.503 & 0.678 \\
\hline JS6 & 0.310 & 0.327 & 0.603 \\
\hline
\end{tabular}

Heterotrait-Monotrait Ratio of Correlations

Lastly the results shown in table 5 from the heterotrait-monotrait ratio of correlations implies that all the values signifies the discriminant validity criteria as none of them are greater than the suggested criteria of 0.9 (Gold et al., 2001) ${ }^{47}$, (Teo et al., 2008) ${ }^{48}$. Therefore it is evidenced that the results shown in table 3, 4 and 5 supports the discriminant validity of the employed constructs i.e. intrinsic motivation, extrinsic motivation and job satisfaction.

Table 5

Heterotrait-Monotrait Ratio (HTMT)

\begin{tabular}{|c|c|c|c|}
\hline Construct & EM & IM & JS \\
\hline EM & & & \\
\hline IM & 0.885 & & \\
\hline JS & 0.819 & 0.580 & \\
\hline
\end{tabular}

Fitness of the research model Q - Square (Predictive relevance)

In order to determine the predictive relevance of the hypothesized path model, blindfolding is performed. It is a sample re-use technique which allows the calculation of

${ }^{47}$ Gold, A. H., Malhotra, A., \& Segars, A. H. (2001). Knowledge Management: An Organizational Capabilities Perspective. Journal of management information systems, 18(1), 185-214. (K. 2003)

${ }^{48}$ Teo, T. S., Srivastava, S. C., \& Jiang, L. (2008). Trust and Electronic Government Success: An Empirical Study. Journal of Management Information Systems, 25(3), 99-132. 
Stone-Geisser's $\mathrm{Q}^{2}$ value (Stone, 1974; Geisser, 1974)49, this value is used as an evaluation criterion for the cross-validated predictive relevance of the path model. The acceptable value of $\mathrm{Q}$ square should be greater than zero, it represents that the model is relevant to predict the factor (Garson, 2016) ${ }^{50}$.

It is shown from table 6 that the Q square value of job satisfaction is greater than zero, i.e. 0.243 which indicates fitness of research the model.

Table 6

Cross Validated Redundancy of the construct

\begin{tabular}{|c|c|c|c|}
\hline Construct & SSO & SSE & $\begin{array}{c}\mathbf{Q}^{\mathbf{2}}(\mathbf{= 1}- \\
\text { SSE/SSO) }\end{array}$ \\
\hline EM & 500.000 & 500.000 & \\
\hline IM & 500.000 & 500.000 & \\
\hline JS & 600.000 & 454.118 & 0.243 \\
\hline
\end{tabular}

Notes: "EM = Extrinsic Motivation, IM = Intrinsic Motivation, JS = Job satisfaction'

\section{R Square (Predictive Accuracy)}

For determining the predictive accuracy of the path model, $\mathrm{R}^{2}$ values are used as the criteria of evaluation. It is also referred to as the coefficient of determination. According to Chin $(1998)^{51}$, the value of $\mathrm{R}$ square is substantial with 0.67 , moderate with 0.33 and weak with 0.19 .

In the present study the R square of Job satisfaction is, 0.618 which indicates that $61 \%$ of the variance in job satisfaction is explained by intrinsic and extrinsic motivation and they created moderate effect size with reference to given criteria by chin.

Table 7

R-Square

\begin{tabular}{|c|c|}
\hline Construct & R Square Adjusted \\
\hline JS & 0.618 \\
\hline Notes: "JS = Job satisfaction"
\end{tabular}

${ }^{49}$ Stone, M. 1974. "Cross-Validatory Choice and Assessment of Statistical Predictions". Journal of the Royal Statistical Society: Series B (Methodological). 36, No. 2: 111-133. \&

Geisser, S. A Predictive Approach to the Random Effects Model, Biometrika, 61, No.1 (1974.):101-107.

${ }^{50}$ Garson, G. D. 2016. Partial Least Squares: Regression \& Structural Equation Models. (G. David Garson and Statistical Associates Publishing, 2016)

${ }^{51}$ Chin, W. W. The Partial Least Squares Approach to Structural Equation Modeling. In G. A. Marcoulides (Ed.), Modern Methods for Business Research, (Mahwah, New Jersey: Lawrence Erlbaum Associates, 1998), 295-336 


\section{Structural Model Assessment and Hypotheses Testing}

The assessment of the structural model is conducted in order to determine the predictive power and analyze the hypothesized relationships between the proposedconstructs through path analysis. The results of the structural model run for the analysis of teacher's motivation and job satisfaction at public sector universities are presented in table 8 .

Table 8

Path Coefficients- Public Sector Universities

\begin{tabular}{|l|c|c|c|c|}
\hline \multicolumn{1}{c}{ Path Coefficients } & \multicolumn{1}{c}{ Effect Type } & \multicolumn{1}{c}{ SRW } & \multicolumn{1}{c|}{ T Statistics } & \multicolumn{1}{c|}{ P Values } \\
\hline H1 EM -> JS & Direct Effect & 0.207 & 2.060 & $\mathbf{0 . 0 4 0}$ \\
\hline H2 IM -> JS & Direct Effect & 0.646 & 6.837 & $\mathbf{0 . 0 0 0}$ \\
\hline H3 Mod. Effect 1(EM -> JS) & Moderating Effect & 0.149 & 2.534 & $\mathbf{0 . 0 2 6}$ \\
\hline H4 Mod. Effect 2 (IM-> JS) & Moderating Effect & 0.227 & 3.892 & $\mathbf{0 . 0 5 9}$ \\
\hline
\end{tabular}

Notes: " $p<0.1, t$-value $>1.96$ indicates significance, SRW = Standardized regression weight, EM = Extrinsic Motivation, IM = Intrinsic Motivation, JS = Job satisfaction"

It is shown from table 8, that the regression path of Extrinsic motivation-> Job satisfaction is significant and implies that Hypothesis 1 is accepted and lying in the significance level $(\boldsymbol{\beta}=\mathbf{0 . 2 0 7}, \boldsymbol{p}<\mathbf{0 . 1})$ it examines the impact of extrinsic motivational factors on job satisfaction of teachers. Likewise, the regression path of Intrinsic motivation $->$ job satisfaction is also significant and implies that Hypothesis 2 is accepted and lying in the significance level $(\boldsymbol{\beta}=\mathbf{0 . 6 4 6}, \mathbf{p}<\mathbf{0 . 1})$.

Also, the moderating effects of total teaching experience with extrinsic motivation and intrinsic motivation are shown separately and the significant results infers the acceptance of hypothesis $3(\boldsymbol{\beta}=\mathbf{0 . 1 4 9}, \mathbf{p}<\mathbf{0 . 1})$ and $4(\boldsymbol{\beta}=\mathbf{0 . 2 2 7}, \mathbf{p}<\mathbf{0 . 1})$ respectively. The results confirmed that as the experience increased the expertise with the job also increased and specifically in public sector, the rewards are designed on the basis of seniority and tenure of service that led towards satisfaction with the job.

Furthermore, the statistical results derived from the data analysis of the private sector universities are shown in table 9. It is reflected from the table that extrinsic motivation creates a significant impact on job satisfaction of private sector university teachers(EM > JS, $\boldsymbol{\beta}=\mathbf{0 . 3 0 7}, \mathbf{p}<\mathbf{0 . 1}$ ).It implies thatthe teachers become motivated with the financial and non-financial rewards provided by the universities and experience high level of job satisfaction. In the same way, intrinsic motivation is found to be the strong determinant of job satisfaction among teachers also (IM $->\mathbf{J S}, \boldsymbol{\beta}=\mathbf{0 . 7 4 6}, \mathbf{p}<\mathbf{0 . 1})$. The discussed results provides the support for the acceptance of hypothesis 1 and 2 with respect to private sector. 
Table 9

Path Coefficients- Private sector universities

\begin{tabular}{|l|c|c|c|c|}
\hline Path Coefficients & Effect Type & SRW & T Statistics & P Values \\
\hline H1 EM -> JS & Direct Effect & 0.307 & 3.060 & $\mathbf{0 . 0 7 0}$ \\
\hline H2 IM -> JS & Direct Effect & 0.746 & 4.837 & $\mathbf{0 . 0 0 0}$ \\
\hline H3 Mod. Effect 1 (EM -> JS) & Moderating Effect & 0.249 & 0.034 & $\mathbf{1 . 5 3 5}$ \\
\hline H4 Mod. Effect 2 (IM-> JS) & Moderating Effect & 0.327 & 0.892 & $\mathbf{1 . 8 9 2}$ \\
\hline
\end{tabular}

Notes: " $p<0.1$, $t$-value $>1.96$ indicates significance, SRW = Standardized regression weight, EM = Extrinsic Motivation, IM=Intrinsic Motivation, JS = Job satisfaction'

Therefore, is evident from the statistical significance that both extrinsic and extrinsic motivational factors are the strong predictors of job satisfaction among university teachers in both sectors as the benefits, rewards, recognition, praise, organizational support, facilitating working conditions, positive work environment and empowerment, all are the motivation driven factors that enhances the enthusiasm for work and results in higher satisfaction with the associated job.

In contrast to findings from public sector universities, it is shown that in the private sector there is no effect of total teaching experience on satisfaction of university teachers with their jobs. As both the moderation effects i.e. with intrinsic motivation $(\boldsymbol{\beta}=\mathbf{0 . 2 4 9}, \mathbf{p}<\mathbf{0 . 1})$ and extrinsic motivation $(\boldsymbol{\beta}=\mathbf{0 . 3 2 7}, \mathbf{p}<\mathbf{0 . 1})$ were found to be statistically insignificant among the teachers belonging to private sector universities and infers the insignificance of hypothesis 3 and 4 .

The results demonstrated that there is no role of teaching experience in determining the strength of relationship between motivation and job satisfaction. Because in private sector, instead of experience, the compensation and rewards and recognition programs are designed on the basis of skills and merit. Hence, the factors that are considered important by teachers are the way in which they are valued by their universities and how they compensate for their services.

In comparison, in view of the statistical results, the study confirms the significant differences between the level of motivation experienced by the teachers and its contribution towards job satisfaction among the both the sectors i.e. public and private universities. The underlying reasons are the dissimilarities in human resource management and employee relations policies designed to recruit and retain the talent inventory.

\section{Conclusions}

In view of the importance of job satisfaction of teachers for the enhancement of high quality education in higher education institutions, the study examined the impact of motivation and experience on job satisfaction of teachers in private and public sector 
universities. For achieving this objective we first explore the motivational factors which leads to job satisfaction and then the role of experience in the field was examined in order to determine the relationship strength of teacher's motivation and their job satisfaction levels.

The results implies that intrinsic motivation and extrinsic motivation are the significant drivers of job satisfaction among teachers irrespective of the university sector, the differences were found with regards to the effect of total teaching experience. Moreover, the findings suggests that the perspective of work motivation and job satisfaction presented earlier by Herzberg's is still verified as the relevant foundation for the determination of job satisfaction. As in the analysis, the study confirms that motivation is indeed a strongest predictor of job satisfaction.

\section{Managerial Implications and Future Recommendations}

The authorities of higher education institutions responsible for talent management should focus on the satisfaction and motivation driven rewards and compensation packages in order to retain its valuable faculty members who imparted quality education to the students and are the pivotal source for the success of the institutions. The universities specifically, the one operating in the public sector should design the reward policies in view of the performance of the teachers as compared to the private sector. Moreover, effective performance management and appraisal systems should be employed in order to gauge the performance and the satisfaction level of teachers.

Moreover in view of the sample limitation to the universities of Karachi, it is recommended for the future researchers to take into account the country wide responses for increasing the generalizability of the research. Also, future studies should explore the factors that are responsible for extrinsic and intrinsic motivation for the effective implementation of those factors in universities to boost the level of motivation among teachers.

\section{Bibliography}

Aswathappa k. (2003). Human Recourse \& Management, pp. 244-245

Bentley, P. J., Coates, H., Dobson, I. R., Goedegebuure, L., \& Meek, V. L. (2013). Factors associated with job satisfaction amongst Australian university academics and future workforce implications. In Job satisfaction around the academic world(pp. 29-53). Springer, Dordrecht.

Bentea, C. C., \&Anghelache, V. (2012). Teachers' motivation and satisfaction for professional activity. Procedia-Social and Behavioral Sciences, 33, 563-567. 
Campbell, D. T., \& Fiske, D. W. (1959). Convergent and discriminant validation by the multitrait-multimethod matrix. Psychological bulletin, 56(2), 81.

Chiu, R. K., Wai-Mei Luk, V., \& Li-Ping Tang, T. (2002). Retaining and motivating employees: Compensation preferences in Hong Kong and China. Personnel Review, 31(4), 402-431.

Daft, R. L., \& Lane, P. G. (2005). The leadership experience (3rd). Mason, Ohio: Thomson South-Western.

Etikan, I., Musa, S. A., \&Alkassim, R. S. (2016). Comparison of convenience sampling and purposive sampling. American journal of theoretical and applied statistics, 5(1), 1-4.

Frederick Herzberg, The Motivation to Work, 1959. (2003). In The Ultimate Business Library, Wiley.

Fornell, C., \& Larcker, D.F. (1981). Evaluating structural equation models with unobservable variables and measurement error. Journal of marketing research, 18(1), 3950 .

Fritsche, K. (1996). Job satisfaction of Texas dietician. UMI.

Gefen, D., \& Straub, D. (2005). A practical guide to factorial validity using PLS-Graph: Tutorial and annotated example. Communications of the Association for Information systems, 16(1), 5.

Gold, A. H., Malhotra, A., \&Segars, A. H. (2001). Knowledge management: An organizational capabilities perspective. Journal of management information systems, 18(1), 185-214. (K. 2003)

Hair, J. F., Ringle, C. M., \& Sarstedt, M. (2011). PLS-SEM: Indeed a silver bullet. Journal of Marketing theory and Practice, 19(2), 139-152.

Herzberg, F. (1959). The motivation to work. New York: Holy Wiley \& Sons.

Hellriegel, D., Slocum, J. W., \& Joyce, W. F. (1976). Instructor's Manual for Organizational Behavior: Contingency Views. West Publishing Company.

Judge, T. A., Locke, E. A., Durham, C. C., \&Kluger, A. N. (1998). Dispositional effects on job and life satisfaction: The role of core evaluations. Journal of applied psychology, 83(1), 17.

Kalleberg, Arne L. Nonstandard Work, Substandard Jobs: Flexible Work Arrangements in the U.S. Washington, D.C.: Economic Policy Institute, 1997. 
Kosteas, V. D. (2011). Job satisfaction and promotions. Industrial Relations: A Journal of Economy and Society, 50(1), 174-194.

Khalid, S., Irshad, M. Z., \&Mahmood, B. (2012). Job satisfaction among academic staff: A comparative analysis between public and private sector universities of Punjab, Pakistan. International journal of Business and Management, 7(1), 126.

Kiviniemi, M. T., Snyder, M., \& Omoto, A. M. (2002). Too many of a good thing? The effects of multiple motivations on stress, cost, fulfillment, and satisfaction. Personality and Social Psychology Bulletin, 28(6), 732-743.

Luthans, K. W., \&Sommer, S. M. (2005). The impact of high performance work on industry-level outcomes. Journal of managerial issues, 327-345.

Lufthansa, F. (2005): Organizational Behavior. McGraw-Hills International Edition

Msuya, O. W. (2016). Exploring levels of job satisfaction among teachers in public secondary schools in Tanzania. International journal of Educational Administration and policy studies, 8(2), 9-16.

Milne, P. (2007). Motivation, incentives and organisational culture. Journal of knowledge Management, 11(6), 28-38.

Machado-Taylor, M. L., Meir Soars, V., \&Gouveia, O. (2010). The role of job motivation among academic staff university. Global Business and Economics Anthology, 2(2), 242246.

Noordin, F., \&Jusoff, K. (2009). Levels of job satisfaction amongst Malaysian academic staff. Asian social science, 5(5), 122-128.

Nadim, M., Chaudhry, M. S., Kalyar, M. N., \&Riaz, T. (2012). Effects of motivational factors on teachers' job satisfaction: A study on public sector degree colleges of Punjab, Pakistan. The Journal of Commerce, 4(4), 25.

Ramayah, T., Jantan, M., \&Tadisina, S. K. (2001, November). Job satisfaction: empirical evidence for alternatives to JDI. In 32nd Annual Meeting of Decision Sciences Institute Conference, Track OB2, San Francisco: USA.

Rao Subba P. (2005). Essential of HRM \& Industrial Relationships, pp.480-482

Raza, M. Y., Akhtar, M. W., Husnain, M., \& Akhtar, M. S. (2015). The impact of intrinsic motivation on employee's job satisfaction. Management and Organizational Studies, 2(3), 80-88.

Raza, S. A., \&Hanif, N. (2011). Factors affecting internet banking adoption among internal and external customers: a case of Pakistan. 
Stankovska, G., Angelkoska, S., Osmani, F., \&Grncarovska, S. P. (2017). Job Motivation and Job Satisfaction among Academic Staff in Higher Education. Bulgarian Comparative Education Society.

Saleem, R., Mahmood, A., \&Mahmood, A. (2010). Effect of work motivation on job satisfaction in mobile telecommunication service organizations of Pakistan. International journal of business and management, 5(11), 213.

Srivastava, A., Locke, E. A., Judge, T. A., \& Adams, J. W. (2010). Core self-evaluations as causes of satisfaction: The mediating role of seeking task complexity. Journal of Vocational Behavior, 77(2), 255-265.

Sinclair, C. (2008). Initial and changing student teacher motivation and commitment to teaching. Asia-Pacific Journal of Teacher Education, 36(2), 79-104.

Sharabyan, S. K. (2011). An investigation into Iranian language teachers' motivation with respect to their job satisfaction and second language pedagogy. Procedia-Social and Behavioral Sciences, 30, 1071-1075.

Tabachnick, B. G., \& Fidell, L. S. (2007). Using multivariate statistics.

Teo, T. S., Srivastava, S. C., \& Jiang, L. (2008). Trust and electronic government success: An empirical study. Journal of management information systems, 25(3), 99-132.

Velnampy, T. (2008). Job attitude and employees performance of public sector organizations in Jaffna district, Sri Lanka. GITAM journal of management, 6(2), 66-73. 


\section{Appendix}

\begin{tabular}{|c|c|c|c|c|}
\hline $\begin{array}{c}\text { Strongly } \\
\text { Disagree (1) }\end{array}$ & $\begin{array}{c}\text { Disagree } \\
\text { Neither agree nor } \\
\text { disagree (3) }\end{array}$ & Agree (4) & $\begin{array}{c}\text { Strongly Agree } \\
(5)\end{array}$ \\
\hline
\end{tabular}

\begin{tabular}{|c|c|c|c|c|c|c|}
\hline S.R.No & Particulars & (1) & (2) & (3) & (4) & (5) \\
\hline \multicolumn{7}{|c|}{ Intrinsic Motivation } \\
\hline 1 & $\begin{array}{l}\text { I am satisfied with the amount of variety of work in } \\
\text { my job. }\end{array}$ & & & & & \\
\hline 2 & $\begin{array}{l}\text { I have no feelings of job insecurity at my } \\
\text { university. }\end{array}$ & & & & & \\
\hline 3 & $\begin{array}{l}\text { I feel motivated with non-monetary rewards } \\
\text { provided by my university. }\end{array}$ & & & & & \\
\hline 4 & $\begin{array}{l}\text { I am getting recognition for extra work at my } \\
\text { university. }\end{array}$ & & & & & \\
\hline \multicolumn{7}{|c|}{ Extrinsic Motivation } \\
\hline 1 & $\begin{array}{l}\text { I feel motivated with the procedure/promotional } \\
\text { policies of my university. }\end{array}$ & & & & & \\
\hline 2 & $\begin{array}{l}\text { I get sufficient financial rewards to meet my } \\
\text { expenses. }\end{array}$ & & & & & \\
\hline 3 & $\begin{array}{l}\text { I have a coach/mentor who keeps me alert \& } \\
\text { motivated to my work. }\end{array}$ & & & & & \\
\hline 4 & $\begin{array}{l}\text { I am satisfied with training and faculty } \\
\text { development initiatives by my university }\end{array}$ & & & & & \\
\hline 5 & $\begin{array}{l}\text { I am satisfied with infrastructure and technological } \\
\text { facilities for convenience of performing work. }\end{array}$ & & & & & \\
\hline
\end{tabular}




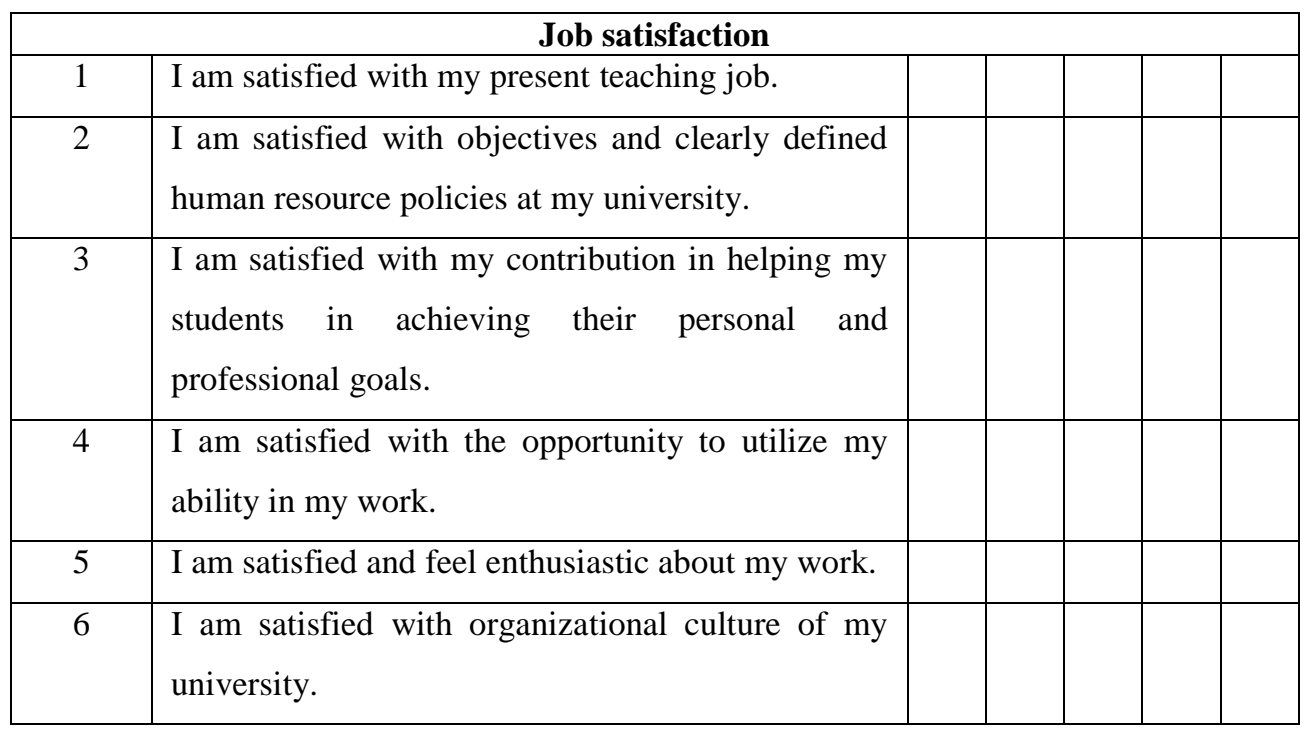

Demographic characteristics

\begin{tabular}{|c|c|c|c|c|}
\hline Gender & $\begin{array}{c}\text { University } \\
\text { sector }\end{array}$ & Age & Qualification & $\begin{array}{c}\text { Total Teaching } \\
\text { Experience }\end{array}$ \\
\hline Male & Public & 20-25 years & Masters & Less than a year \\
\hline Female & Private & $26-30$ years & MS/M.Phil. & $1-3$ years \\
\hline & & $31-35$ years & PhD & 4-6 years \\
\hline & & $\begin{array}{c}\text { 36-40 years } \\
\text { Above } 40 \\
\text { years }\end{array}$ & & $7-9$ years \\
\hline & & Above 10 years \\
\hline
\end{tabular}




\section{Path Coefficients}

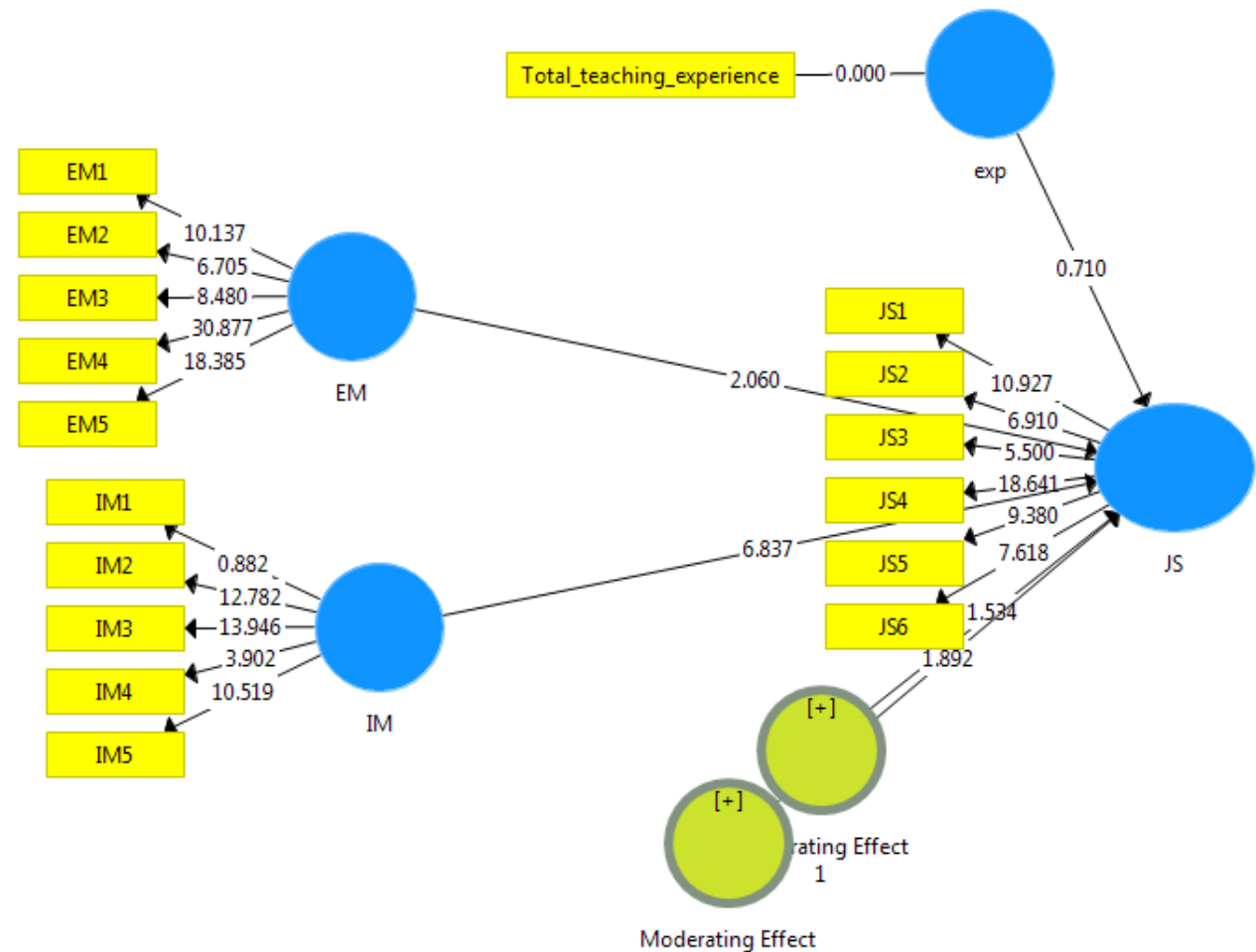

2 